\title{
Pesantren as the Basis of Development of Political Ideology in the Digital Era
}

\author{
Zainal A. Rahawarin \\ State Institute of Islamic Studies (IAIN) of Ambon, Maluku-Indonesia \\ e-mail: za.rahawarin20@gmail.com
}

\begin{abstract}
This study aims to investigate the role of Islamic boarding schools as the basis for developing political ideology in the digital era. The research design used is a qualitative approach. The research location is in Ambon, Indonesia. This research was conducted in 2 Islamic boarding schools with 2 pesantren caregivers, and 10 $u s t a d z$ at the two Islamic boarding schools. Data were collected through observation, interviews, and documentation that focused on three themes, namely the role of Islamic boarding schools, political ideology, and the digital era. The findings in this study reveal that the role of Islamic boarding schools contributes to the strengthening of political ideology in the digital era. The role of the pesantren is carried out through the khalaqoh contained in the pesantren. Khalaqoh is in the form of khalaqoh toriqoh, and also in the form of khalaqoh organization. The perpetrators of the development of political ideology revealed in this study were carried out by the Kyai, as well as the ustadz who was trusted by the Kyai to be badals or substitutes. The development of political ideology through activities in the toriqoh congregation and also the organization's congregation was fairly high. Meanwhile, the weaknesses found in the political ideologicalization by pesantren are not prioritizing the literacy side where the santri and the congregation in the context of ideological politicization tend to be passive. The role of Islamic boarding schools in the digital era continues to contribute to the community to increase their capacity as contributors to the development of political ideology.
\end{abstract}

Keywords: digital era, Islamic boarding school, political ideology 


\section{A. Introduction}

The role of pesantren in Java has been recorded since 1819. This is as stated in the decree of the governor-general Van der Capellen who is committed to conducting research in Java (Chijs, 2012). In the research report, it was found that there were several people who taught in Java, especially teaching Arabic/pegon writing, Javanese and Latin languages. In addition to learning to write, the study also explained that educated people also developed strengths in an effort to make their blood spilled with dignity. With regard to Islamic boarding schools in Ambon, Indonesia, that Islamic boarding schools in Ambon, already have educational institutions. In the report, it is unfortunate, because it is not complete with the education system, let alone the curriculum in the institution. Mohamad Radjab and Achmad Djajadingingrat, Islamic scholars in Indonesia, noted a little about the educational methods and curriculum for Islamic boarding schools on the island of Java (Gonggong, 1985). From this historical record, it can be seen that the function of pesantren was initially as an educational institution (Steenbrink, 1986).

As a subculture, pesantren is perhaps one of the oldest traditional education systems in Indonesia that focuses on the process of learning Islamic religious knowledge both about language science, monotheism, Qur'anic science, Hadith science, and others. This is found in the pesantren system, which places the figure of the Kyai as the center of knowledge. The majority of students, called santri, live in Islamic boarding schools 24 hours every day.

A more comprehensive understanding of pesantren comes from Azra (2007) quoted by Ismah (2011). Pesantren is a residential school dedicated to the transmission of classical Islamic sciences, including the study of the Qur'an and hadith, fiqh, Arabic grammar, Sufism, and Arabic linguistic sciences (tools). The special location complex for the pesantren consists of a mosque, study rooms, dormitories, and houses of kyai (ulama who build and lead the pesantren), canteen, field, public kitchen, office, and parking lot.

Students stay there 24 hours a day/week, not only for school but also for all their daily activities, such as eating, washing, cooking, sports, martial arts, skills training, gardening, art training, literacy training, etc. The students study many subjects related to traditional Islamic subjects from theology to Arabic grammar, from Islamic jurisprudence to theology and philosophy. Today, pesantren has a very big role in the development of ideology through various literature that develops there. There is a lot of literature produced by Kyai in instilling religious values, ideologies, and principles (Ismah, 2011).

The ideology of Islam, juxtaposed with the ideology of Pancasila, Democracy, can be studied together well. The majority of pesantren do not contradict these three things, even though they are studied together. Indeed, there are some Islamic boarding schools that are supervised by the security forces, while teaching the ideology of Islamic countries strictly. Islamic boarding schools must continue to recognize Pancasila as the basis of the state, Islam as a religion, and democracy as the basis for living as a nation and state.

Furthermore, in line with the development and the existing situation, the pesantren still exists in the community. The existence of pesantren cannot be separated from the role of the Kyai as the main captain in managing and developing pesantren institutions. Pesantren in the era of struggle had an important role in the process of planting political ideology to achieve independence. Pesantren in the post-independence era also had a big role in filling independence. Furthermore, in the context of democracy, Islamic boarding schools still 
always exist in contributing to making pesantren as a forum for the development of political ideology. Indications of this development can be seen, when many pesantren are affiliated with political parties in order to develop democratic life.

The presence of pesantren in the process of inculcating political ideology becomes increasingly visible when pesantren is recognized and occupies a position as a developer and balancer for the growth of moderate thinking. This is evidenced by the presence and number of pesantren alumni who occupy strategic positions in the arena of democracy. For example, pesantren alumni become presidents, pesantren alumni become regional heads, pesantren alumni become ministers, and so on (Wahid, 1988).

From a background that focuses on the role of pesantren in planting political ideology, the subjects of this research are two major Islamic boarding schools in Ambon Indonesia. The purpose of this research is to find out how boarding schools perform their functions as cultivators of political ideology in the digital era. From the purpose of this study, the formulation of the problem in this study is "How is the role of Islamic boarding schools in instilling political ideology in the digital era?"

\section{B. Literature Review}

\section{Pesantren (Islamic Boarding School)}

In this study, the researcher took the object of research was pesantren (Islamic boarding school). The academic reason for this study is that pesantren is one of the oldest institutions in existence. This position is supported by the fact that pesantren is a da'wah institution. With this position, Islamic boarding schools are expected to act as agents to realize and change a condition, including through the embedding of political ideology in today's digital society. According to Wahid Zaini, Islamic boarding schools have a strategic role in the current Globalization scene. The first role is as a da'wah institution, the second is as a place for the cadre of scholars, the third is the development of knowledge, and the fourth is as a community development institution (in this case it can be intended as a developer of political ideology in society) (Zaini, 1994).

Pesantren is a unique area, where the uniqueness is not owned by other than the pesantren. Related to this, Abdurahman Wahid explained that the elements of Islamic boarding schools are Kyai, santri, mosques, cottages, and teaching classical books. The concept proposed by Abdurahman Wahid in the context of this research is very important for us to borrow as an analytical tool. The basic reason for the pesantren element is the Kyai. The first thing, in the context of planting political ideology, we can use that the position of the Kyai as a figure in an educational institution is as an actor. Not only actors in certain scientific fields, but also actors in their position as support for the cultivation of political ideology. This is what happened at the Islamic boarding school with a very charismatic Kyai figure who benefited from the development of his influence in the field of political ideology. With his charismatic influence, a Kyai only teaches his students to build and develop the concept of political ideology and can directly implement it by also developing political concepts in the institutional arrangement of pesantren (Daulay, 2001).

The second point of Abdurahman Wahid's opinion for our analysis is the santri (Wahid, 1988). Santri were the sub-objects of this research, since the facts on the ground that the perpetrators of political ideology are people who have enthusiasm. The spirit is 
synonymous with young people. Santri are people who are still young and it is very possible that they will become actors in developing the world of politics and bringing about change in society. Another element as stated by Abdurahman Wahid is related to the mosque. The mosque here also turned out to be a place of contestation for the students. From this side, it is hoped that political actors who have ideology will emerge, who depart from the mosque arena, in which it is clear that they are santri.

\section{Political Ideology}

A political ideology is a set of ideas and principles that explain how citizens should perform their jobs, and offer a summary of the orders of a particular citizen. Political ideology is mostly about itself how to organize power and how it should be exercised. In general, the principle of understanding political ideology can be understood that this ideology is closely related to how one places oneself in the process of regulating power. Not only in form of political parties, the ideological power can also be found in education. Laursen (2006)) argues that the basic form of power in education is the ideological power that can make learning seem reasonable to the students. In the context of this research, Islamic boarding schools have the full right to determine the direction of their power. Pesantren has its own identity in asserting the desired power principle. Of course, in this case, pesantren cannot be alone in terms of being only a Kyai, but pesantren as an institution makes itself manifest in a society that is firmly rooted in a complete belief in people's lives.

Activities carried out by Islamic boarding schools can be interpreted as an activity of planting political ideology, because these activities are not only meant to uphold religious teachings as set out in the curriculum and agenda, pesantren activities indirectly emphasize the function of Islamic boarding schools and their completeness as cultivators of political ideology. With a pesantren, a Kyai is able to show his existence, mastering the understanding of students and the surrounding community, even in a democratic party, a Kyai becomes the center of voting (Aljabiri, 2001).

\section{Digital era}

In general, the digital era is a condition of life or an era where all activities that support life have been made easier by the presence of technology. In this study, the researcher tries to see a condition that is happening at this time. Where the current condition is the occurrence of very rapid changes in all lines of life. Human life which was originally analog has now changed to all digital. In research, digitization is an important moment, the connection is when pesantren are in this condition, pesantren are in fact able to survive and continue to exist. Even the presence of digital values does not discourage lovers of Islamic boarding schools to remain involved in them (Amirullah, 2015).

The community remained patiently waiting for the presence of the pesantren which was making technical adjustments to the activities carried out by the pesantren. Next, this can be seen when Islamic boarding schools have succeeded in making adjustments to the digitalization phenomenon. Santri are still enthusiastic about connecting themselves with the pesantren through digital media prepared by the pesantren. Another phenomenon is the emergence of digital boarding schools. From this phenomenon, it shows that Islamic boarding schools are in a completely digital condition, a thesis can be drawn that Islamic 
boarding schools have a major role in the process of planting political ideology for the community (Arfiansyah, 2010).

\section{Pesantren and Ideology}

Pesantren as a sub-system of national education is still believed to be one of the best education in the archipelago (Arkoun \& Gardet, 1997). The existence of Islamic boarding schools still has a special place in the hearts of Muslims, although lately other modern educational institutions are increasingly crowded (Mukodi, 2016). Moreover, for nahdhiyin people who live in urban areas, aka 'periphery' people. In fact, not a few Muslim puritans consider boarding school education as important as formal education (schooling) for their children (Asril, 2015)

Political education is one of the various types of education that is built and developed in Islamic boarding schools. However, methods and methods are not designed, let alone prepared properly. In fact, the owners - Kyai, ustad, and administrators - are not aware that they have taught the values of political education in pesantren. Various activities that lead to the education of political basics such as freedom of expression, respect for differences, tolerance, and culture have been practiced in pesantren (Mukodi, 2014). There are at least five activities in Islamic boarding schools that condition students to understand political values, namely: 1) book discussion forums (deliberations) (Abdullah, 2000); 2) the study of al-Fiqh 'alāal-Madhāhib al-Arba'ah; 3) khițābiyah forum; 4) the practice of democratic culture; 5) study of bath al-masāil (Mukodi, 2015).

Freedom of opinion and choice which is the main characteristic of democracy has actually been practiced for years in various Islamic boarding schools in Indonesia (Rahman, 2006). This is reflected in the way students choose teachers, and the yellow book at the time of bandongan, or wetonan. This kind of condition is the same as the Semester Credit System in the world of lectures at universities. More than that, the students' freedom of opinion, attitude, and action are also practiced by the students in their daily lives (Chasbullah, 2014). Although the patron-client culture in Islamic boarding schools still exists, the quality is starting to decline so that the students are more independent in their attitudes, opinions, and actions (Triono, 2011).

The political education obtained by the students in the study of bath al-masail is very diverse and has a lot of meaning (Tohari, 2012) This is because, in each subject, bath almasail is based on social issues (Gantar, 2015). The issue of nationality, state defense, and national politics is a series of problems that are often sought for solutions in the study of bath al-masāil (Zaini, 2015; Fealy \& Barton, 2010; Castle, 2007).

The most important point that must be understood is that through the study of bath almasāil, the entire academic community of Islamic boarding schools-Kyai, Kyai families, managers (Marianti, 2009), administrators, ustad, courtiers, and students - can learn and understand political issues in-depth (Mulkhan, 1999). In addition, the study of bath al-masāil on political issues also ignited a sense of politics, as well as political awareness for students in Islamic boarding schools. Moreover, the participation and activeness of the civitas of Islamic boarding schools in participating in various bath al-masāil discussions, especially on political topics, can condition themselves into unconsciousness in the political realm. In the 
future, they will no longer be allergic to political practices in the real world (in society), even making politics a part of their da'wah tool (Sunaryo, 2014).

\section{Research Methodology \\ 1. Research Design}

This research is a qualitative case study phenomenology. We include it in qualitative research as conveyed by Bogdan \& Biklen (1982) because this research has natural direct sources, where the researcher is the key instrument. Furthermore, this research prioritizes descriptions or expressions that take precedence over processes (outcomes or products). Qualitative research that we mean is research that demands more participant perspectives. Furthermore, the case study is meant to be research conducted on one person or group of people, as well as other areas (Fraenkel \& Wallen, 1990).

\section{Participants}

In this study, researchers took the setting at Islamic Boarding School, in Ambon Indonesia. The selection of this place is assuming that this place is representative and can represent the context of the pesantren which has a role as a cultivator of political ideology in Ambon. These considerations and reasons are what researchers are interested in and assume that they are worthy of being used as research samples. Specifically, the researcher will take the Kyai as the participants, as well as the congregation/santri in each of the pesantren.

\section{Data and Data Sources}

Data collection techniques are carried out by photographing, viewing, sorting, and analyzing various phenomena in entrepreneurial boarding schools which we consider as primary data (Mantra, 2004). In addition, researchers conducted participatory observations, namely by observing the activities and activities of Islamic boarding schools in Ambon. In order to complete the data, the researcher also used the interview method, this method was carried out by conducting interviews with the managers or key figures of the pesantren. The key figures that we mean here are the managers who are at the pesantren, the Kyai, and this includes the students.

\section{Theme Instrument}

The instrument in this study focuses on two things, namely the first about the role of Islamic boarding schools in embedding political ideology, the second is about the path of embedding political ideology, and the third is related to the embedding of political ideology in the digital society. From the three main themes, specific indicators were selected, which were then reduced to questions to collect data. From the data obtained, then data validation is carried out by triangulation, and matching data between one source and another.

\section{Data Collection}

As a material for analysis, researchers collected data using the methods of observation, interviews, and documentation. Observations are carried out at certain times, for example, during religious events that are As a As a material for analysis, researchers collected data using the methods of observation, interviews, and documentation. Observations are carried 
out at certain times, for example, during religious events that are carried out using digital media. Program One such example is the khalaqoh event held by a boarding school. Meanwhile, our interviews were conducted in person. Taking into account the current situation and conditions, direct interviews were carried out with strict procedures. Meanwhile, to complete the lack of existing data, the researchers conducted interviews using WhatsApp media. In addition, to complete the data, the researcher collected data with documentation. Documentation includes activities that involve students or congregations. For example, youtube which is documented by pesantren.

\section{Data Analysis}

Data analysis can be interpreted as an effort to find and organize data systematically. Furthermore, this data is presented as findings in order to improve understanding. The essence of this concept is that it is intended to present research findings to the readers. In this plain, the researcher occupies as the revealer of meaning on the basis of data and proceeds through a clear analysis. From this process it can be seen that researchers in the qualitative research process have mandatory activities in the form of writing, editing, clustering, reducing, presenting data, and drawing conclusions and verification (Muhadjir, 1998). The analysis is carried out together with data collection with the stages of collecting, condensating, presenting, and verifying or drawing conclusions (Miles, Huberman, \& Saldana, 2014). An important step in this research is triangulation. Where this process includes data source triangulation, method triangulation, investigator triangulation, and theory triangulation. In this study, researchers used three triangulation processes, namely data triangulation, methods, and theories. The data triangulation process is carried out by cross-checking. This is implemented by matching the interview data with observations. The second triangulation is method triangulation, this is carried out by checking data through interviews. The third triangulation is theoretical triangulation, this is done by synchronizing real data with the results of action observations in the field.

\section{Findings and Discussion}

\section{The Role of Islamic Boarding Schools in Embedding Political Ideology}

\section{a. The Position of Pesantren in Embedding Political Ideology}

Pesantren has a strategic side in planting political ideology. Where the elements of the pesantren, as conveyed by Abdurahman Wahid (Kyai), have a central goal. The centrality of the Kyai's role in the pesantren cannot be replaced by other figures. So that in the process of planting political ideology, Islamic boarding schools have a very strategic role.

The strategic side of the pesantren in planting the second political ideology is related to the object of the pesantren. The object of learning and ideological belonging to the pesantren is the santri. Apart from the students, there is another object, namely the congregation. Students who have specifications are people who still tend to be young. In practice, the average age of the santri is between ten and twenty-five years. In such a fact, pesantren is an agent of political ideology planting carried out by a Kyai. Where the political ideology that occurs in Islamic boarding schools in Ambon is actually not the main side but is only a side effect. This is because the main side of pesantren is actually the cultivation of religious 
values based on Shari'a knowledge in accordance with Islamic teachings. while the political ideology is embedded because of the element of respect for a santri towards the Kyai. With this atmosphere of reverence or respect, it finally manifests like the conditions of the power of a Kyai in an Islamic boarding school. This is understood in this study as the actualization of the value of political ideology.

Another object in conveying the political ideology of Islamic boarding schools is found in the congregation. Congregations in this context are those who declare themselves to follow the Kyai in order to learn. In terms of age, the congregation has a higher age level than the santri. The average age of the congregation is those who are more than thirty years old. Ideology in the object of the congregation is very visible when many pilgrims declare their loyalty to a Kyai in a boarding school.

So with this expression of loyalty, the congregation does not hesitate to always leave all his affairs to the Kyai. The beginning of this attitude is to get blessings from the Kyai. However, in the context of political ideology, such things are included in the realm of upholding the political ideology of pesantren for the community.

\section{b. Pesantren Activities to Inculcate Political Ideology}

In an effort to carry out Islamic boarding schools, their work programs or activities cannot be separated from the plan. Where the planning of Islamic boarding school activities is the main basis for the pesantren agenda in carrying out the process of serving the community using knowledge. The main vision echoed in the pesantren to instill religious ideology is to worship God Almighty. However, in practice, the effort to realize this vision also has an impact on the political ideology of pesantren in society.

The form of planning for pesantren activities in religious activities includes planning activities through toriqoh. As is known in general, that toriqoh is a congregation that aims to get an imam or leader. Furthermore, the leader or priest provides reading practice to be practiced. All of that as an effort to find peace and find a way of salvation in accordance with his beliefs. It is from this practice that the planting of political ideology is seen again. The Imam who is usually called a murshid has absolute power in front of the congregation. With this power, a murshid has the power to direct his congregation in any direction on the basis of his beliefs.

The another plan is through organizational activities. Organizational activities owned by pesantren include KeNUan activities. This activity is an activity that is planned to provide knowledge to the congregation and students regarding the nature of NU. The NU referred to here is Nahdlatul Ulama. NU has become a vital organization for pesantren. This is because in addition to $\mathrm{Nu}$ has a populist principle, also in $\mathrm{NU}$ there is ma'had fikroh or way of thinking. Inside NU, the congregation and Santi are invited to harmonize their views. With this relatively harmonious and similar view, the role of Islamic boarding schools becomes more actual. Pesantren became the basis of NU as well as a strength for planting political ideology. Islamic boarding schools with NU material are becoming more actual in their strength and their role is increasingly visible in strengthening political ideology. 
c. The Media Used by Pesantren in Embedding Political Ideology

In the process of planting the political ideology of Islamic boarding schools using the media currently, the researchers can compare. The comparison is related to the development of the phenomenon that occurs. Islamic boarding schools are forced to carry out an adjustment process. The adjustment process includes using digital media, for example, such as selapanan recitation, toriqoh recitation, and general recitation to students and congregations are carried out virtually. In the context of the use of virtual media, it appears that the political ideology of pesantren is getting stronger. This can be seen by the indication that, when a Kyai as the central figure of the pesantren appears and delivers recitation material, a large number of students and worshipers flock to come virtually.

In addition, the media used also uses radio media. Radio has a place and position for the older generation of santri, namely the age of forty years and above. This is because the congregation of that age is less skilled in the use of social media such as YouTube and also zoom meetings and the like.

\section{d. The Obstacles Experienced by Pesantren in Instilling Political Ideology}

Islamic boarding schools in playing themselves as cultivators of political ideology did not run smoothly. This means there must be obstacles. These constraints include those related to economic constraints. The economic condition of a santri or congregation has a significant effect.

From the constraints of economic conditions, here affects the mindset of students and congregations. Santri who was initially devoted to direct learning were forced to study using social media. Congregants who are accustomed to being solemn, taking part in various toriqoh activities and public education, are forced to learn to use social media or at least just listen to the radio. This condition is clearly an obstacle for Islamic boarding schools in their actualization efforts to make pesantren as planters of political ideology in the digital era.

\section{Embracing Political Ideology}

a. Steps for pesantren in instilling political ideology.

Pesantren in the process of cultivating political ideology cannot be separated from the path it takes. The route is divided into two. The first is through the toriqoh congregation. The second is to use the organizational path. If compared between these two paths have the same power. The power is the first that both are mass-based congregations. In the use of these two paths, the pesantren puts forward the concept of kinship.

The path of the toriqoh congregation referred to here is the path taken by the pesantren in the process of planting political ideology. Where in this congregation the pesantren positions itself as the central institution. Pesantren with its mosque elements makes the mosque as a place for the process of holding meetings. In the process of the meeting, the pesantren conveyed its teachings through the Kyai. On this occasion, as a side effect of the existence of the pesantren toriqoh congregation, it shows its existence to make itself as a reinforcement of the power of power in controlling the masses. In addition, through toriqoh, the amaliah of the congregation is also controlled so that it can be controlled by the pesantren through the presence of a Kyai. 
The second path in the form of organization is the second path taken by pesantren in instilling political ideology. In the congregation of the NU organization as described above, the researcher found an element of a mass-based power contest. This is one form of the existence of pesantren in organizing the masses through religious organizations.

\section{b. The subject of planting the political ideology of pesantren.}

There are two main subjects in the planting of political ideology carried out by pesantren. The first object is the santri, the second object is the congregation. Santri as the first object in the process of inculcating political ideology, this is because students expressly through their guardians surrender themselves to study to others Kyai in a pesantren.

In this condition, the lessons or material conveyed by a Kyai in a pesantren will be firmly entrenched in the mind of a santri. A student in an interview explained that the process of surrendering oneself to learning is not taklid as understood in the context of blind taklid. However, the taklid carried out is in the context of khusyu' learning and following the behavior of the Kyai as a reference in his life.

The second subject is the congregation. The congregation in this case is still divided into two, namely the special congregation and the general congregation. Special congregations are those who are members of the toriqoh congregation. While the general congregation is those who are members of the general recitation congregation. Pesantren generally have these two types of congregations. In the process of learning and inculcating views about religion, pesantren always provide an understanding of religion. Along with the embedded understanding, will continue with the embedded belief in the truth of what is contained in the pesantren program that he follows. In this condition, a congregation will not rethink the framework of truth, which is a belief in the material presented in the congregation of the pesantren. This context brings the congregation into a controlled atmosphere of the power of the pesantren as an institution that cultivates political ideology. In this context, the pesantren again shows its existence, that when the congregation wants to find the truth, they will return everything they face to the pesantren.

\section{c. The method of planting political ideology}

In the process of planting political ideology, pesantren uses two methods. This is based on the occurrence of a world phenomenon. The first method is the conventional method. While the second method is the virtual method. The conventional method was carried out during normal conditions in the normal situation without any big issue of the economy, social, or culture. This is done through an oral delivery process by the Kyai or team in the toriqoh congregation. The Kyai team is usually scattered in various regions. This team is better known as badal. This method is carried out in the context of congregational clustering in order to anticipate the occurrence of distance constraints experienced by the pilgrims to come to the center of the Kyai congregation at the Islamic boarding school. With another understanding. This method is an effort to establish sub-learning to provide learning material ketoriqohan and organization.

The second method is an alternative step, where the occurrence of sensitive issue in the society, such as health, economical, or political issues that brought the pesantren in an emergency situation so that the pesantren carried out the adjustment process. The second 
method is the virtualization method. This method in the concept of learning is better known as online. In principle, the material presented is the same between in-person meetings and virtual meetings. Instilling an understanding of religion still contributes to the congregation to return themselves, their souls, and bodies to the pesantren. This is where the process of internalizing political ideology in the context of mastery of a person as an individual as well as a group occurs.

\section{Embedding Political Ideology in the Digital Society}

a. Islamic boarding schools see digital phenomena as a gap to instill political ideology.

There are interesting things in the implementation of virtualization of meetings in the midst of revolution industry era 4.0. That it turns out that the virtualization path actually creates a gap for pesantren to further actualize themselves in the arena of planting political ideology. As explained in the theoretical level above, that political ideology is not only limited to efforts in the democratic process but more than that, pesantren can also be classified as an institution that cultivates political ideology.

This is in principle and in juridical ideological terms, nationality is not in conflict with the life of the nation and state. Likewise, it does not conflict with other forms of life. In the context of democracy, the planting of political ideology carried out by Islamic boarding schools actually enriches the world of democracy. Where control and control of the masses will minimize the occurrence of internal conflicts in society. Moreover, the occurrence of major conflicts in society.

The digital era brings its own blessings to Islamic boarding schools, through virtual media, Islamic boarding schools can facilitate their work plans to target the object of planting religious understanding more broadly. In this gap of the research, it was found that Islamic boarding schools have a strategic position in the arena of planting political ideology in the midst of a digital society.

Another positive value obtained by Islamic boarding schools in today's digital era is the occurrence of a material development system. Through virtual media, pesantren can be easily accessed by various groups and levels of society. Where it also does not rule out the possibility of two-way communication and discussion.

\section{b. Characteristics of digital society from the perspective of Islamic boarding schools}

Islamic boarding schools in their actualization process in digital society try to define the digital society itself. As stated by the manager of the pesantren, that digital society is those who in their daily lives use information technology and telecommunications, and want to get something that is known quickly, precisely, and accurately. So in this case the pesantren has been seen to be open to making adaptive adjustments to the situation and conditions that occur.

\section{E. Conclusion}

The role of pesantren in contributing to the strengthening of political ideology in the digital era. The role of the pesantren is carried out through the khalaqoh contained in the pesantren. Khalaqoh is in the form of khalaqoh toriqoh, and also in the form of khalaqoh organization. The perpetrators of the development of political ideology revealed in this study 
were carried out by the Kyai, as well as the ustadz who was trusted by the Kyai to be badals or substitutes. In addition, the object of the development of political ideology in this study is the santri in the pesantren and also the congregation who are members of the toriqoh congregation and also the organization's congregation. In the observation, it was found that the development of political ideology through activities in the toriqoh congregation and also the organization's congregation was fairly high. Meanwhile, the weaknesses found in the political ideologicalization by pesantren are not prioritizing the literacy side. Where the santri and the congregation in the context of ideological politicization tend to be passive. The development of political ideology can be positioned in a strategic position, where the role of pesantren will be increasingly advanced in the community if only there is continuity and a systematic reference based on developing a religious-political system. Religious political ideology will present a conducive democratic situation as mandated in the 1945 Constitution. The role of Islamic boarding schools in the digital era continues to contribute to the community to increase their capacity as contributors to the development of political ideology according to their time.

\section{BIBLIOGRAPHY}

Abdullah, M. (2009). Khasanah Sastra Pesisiran. Undip Press.

Aljabiri, M.A. (2001). Agama, Negara, dan Penerapan Syariah.transl. Mujiburrahman. Fajar Pustaka Baru.

Amirullah. (2015). Hubungan Islam, dan Politik di Indonesia Serta Implikasinya Terhadap Pendidikan Islam. Jurnal Kreatif, 12(1).

Arfiansyah. (2010). Pemikiran Politik Islam; Sebuah Tinjauan Sejarah Terhadap Arus

Pemikiran Islam Klasik Sampai Awal Abad Ke 20. SUBSTANTIA, 12.

Arkoun, M., \& Gardet_L. (1997). Islam Kemarin, dan Hari Esok. transl. Mujiburrahman.

Penerbit Pustaka.

Asril, S. (2015). Mendagri: 343 Kepala Daerah Tersangkut Kasus Hukum. Kompas.com, 4 Februari.

Azra, A. (2007). Revitalisasi Islam Politik dan Islam Kultural diIndonesia. Indo-Islamika, 1 Bogdan, R.C. \& Biklen, S.K. (1982). Qualitative Research for Education. Allyn and Bacon Castle, G. (2007). The Blackwell Guide to Literary Theory. Blackwell Publishing.

Chasbullah, KH. W. (2014) "Syirkatul 'Inan Murabathoh Nadlatul Tujjar." In Kumpulan Tulisan Majma’ Buhuts An-Nahdliyyah (Forum Kajian Ke-Nu-An). Majma’ Buhuts AnNahdliyah,.

Chijs, Van Der. (2012). Bijdragen tot de gesebiedenis van bet inlandscb onderwijs. Perpustakaan Nasional RI

Daulay, H.P. (2001). Historisitas dan Ensisitas Pesantrendan Madrraasah. Tiara Wacana

Fealy, G. \& Barton, G. (2010) Tradisionaisme Radikal Persinggungan Nahdlatul UlamaNegara. LKiS.

Fraenkel, J.R. \& Wallen, N.E. (1990). how to design and Evaluate Research in Education. Mc Graw-Hill Publishing Company 
Gantar, D. (2015) "Biografi Tan Malaka." academia.edu, 2016. "Inilah Hasil Bahtsul Masail Muktamar NU ke-33 di Jombang." Bahtsul Masail, 24 Agustus 2015. santri.net.

Gonggong, A. (1985). H.O.S Tjokroaminoto. Departemen Pendidikan dan Kebudayaan.

Ismah, N. (2011). The New Generation of Women Writers from the Pesantren Tradition in Indonesia. Exploration (A Graduate Student Journal of Southeast Asean Studies), Vol. $11(1)$.

Laursen, Per f. (2006). Ideological Power in Education, European Educational Research Journal, 5, Numbers 3 \& 4, 2006

Mantra, I.B. (2004). Filsafat Penelitian dan Metode Penelitian Sosial, Cet I. Pustaka Pelajar Marianti, M.M (2009). "Kepemimpinan Sifat.” Bina EkonomiMajalah Ekonomi Unpar 13

Miles, M. B., Huberman, A. M., \& Saldana, J. (2014). Qualitative Data Analysis: A Methods Sourcebook. SAGE Publications.

Muhadjir, N. (1998). Metodologi Penelitian Kulaitatif. Andi Offset

Mukodi, M. (2016) Pesantren Dan Pendidikan Politik Di Indonesia: Sebuah Reformulasi Kepemimpinan Islam Futuristik. Al-Tahrir: Jurnal Pemikiran Islam, 16(2)

Mukodi. (2014). Studi Fenomenologi Budaya Pondok Tremas di Era Globalisasi. Universitas Negeri Yogyakarta.

Mukodi. (2015) Menjaga Umat Pilar-Pilar Budaya Pondok Tremas di Era Global. Lentera Kresindo.

Mulkhan, A.M. (1999). Runtuhnya Mitos Politik Santri Strategi Kebudayaan dalam Islam. Sipress.

Rahman, B.M. (2006). Ensiklopedi Nurcholish Madjid Pemikiran Islam di Kanvas Peradaban. Penerbit Mizan.

Steenbrink, K.A. (1986). Pesantren, Madrasah, Sekolah: Pendidikan Islam dalam Kurun Modern. Lembaga Penelitian, Pendidikan dan Penerangan Ekonomi dan Sosial.

Sunaryo, A. (2014). Simbolisme dan Essensialisme Kepemimpinan (Kajian Fikih Siyasah Tentang Sosok Pemimpin Ideal MenurutIslam). AKADEMIKA, 1

Tohari, Ahmad. (2012). Kubah. Gramedia Pustaka Utama.

Triono. (2011) "Corak Pemikiran Politik dalam Islam Zaman Klasik, Pertengahan dan Kontemporer." Jurnal TAPIs. Vol. 4(2).

Wahid, Abdurrahman. (1988). 'Pesantren sebagai Subkultur' in Dawam Rahardjo (Ed.), Pesantrendan Reformasi. LP3ES, $4^{\text {th }}$ printed.

Zaini, A.W. (1994). Dunia Pemikiran Kaum Santri. LKPSA.

Zaini, H.F. (2015). Pesantren Akar Pendidikan Islam Nusantara. P3M. 